\title{
Studying lung cancer in the laboratory: 3-Use of cell lines to investigate the biology of lung cancer
}

Our understanding of the origins and biology of lung cancer has been enhanced in recent years by the development of laboratory systems that permit the continued growth and characterisation of tumour cells taken from the patient. Most of this work has been performed by establishing small cell lung cancer cell lines in tissue culture.

\section{Evaluation of biological products}

Ectopic production of polypeptide and steroid hormones has been well documented in patients with small cell lung cancer ${ }^{12}$ and in small cell lung cancer xenografts. ${ }^{3-5}$ The use of defined serum free media has allowed easy evaluation of the production of these substances by small cell lung cancer cell lines. ${ }^{67}$ In one study of 13 different lines, ${ }^{7}$ appreciable amounts of 14 different hormones were found, with up to 10 different hormones produced by any one cell line. The exact meaning of hormone production by these tumours in patients is unclear. Some studies have shown a positive correlation between serum concentrations and extent of disease or clinical response ${ }^{89}$ while others have found no such effect. ${ }^{25}$ No attempt has been made to clarify this problem by studying hormone production by tumour cells in vitro.

Recently much interest has been shown in the production of three other biological "markers" by small cell lung cancer cell lines. Neurone specific enolase, the neuronal form of the glycolytic enzyme enolase, has been found in neuroendocrine (APUD) tumours and is secreted by small cell lung cancer cell lines. ${ }^{10} 11$ The BB isoenzyme of creatine kinase (CKBB) has also been detected in large amounts in small cell lung cancer cultures ${ }^{12}$ but, like neurone specific enolase, is not found in non-small cell lung cancer cell lines (table). A good correlation between serum concentrations and both disease extent and response to treatment has been demonstrated for both these

Address for reprint requests: Dr $\mathbf{R} \mathbf{J}$ Fergusson, Imperial Cancer Research Fund Medical Oncology Unit, Western General Hospital, Edinburgh EH4 2XU. markers in patients with small cell lung cancer, ${ }^{12}$ and $\stackrel{\vec{N}}{\sim}$ one report suggests that CK-BB may be useful as a $\vec{N}$ diagnostic aid in cases of occult tumour. ${ }^{13}$

The neuropeptide bombesin, which occurs physio- $N$ logically at low concentrations in many tissues, has 5 been shown to be produced at high concentrations by $\vec{\square}$ small cell lung cancer cell lines. ${ }^{14}$ is Specific membrane $\Phi$ receptors for bombesin and related peptides have been $\Phi$ identified on small cell lung cancer cells ${ }^{16}$ and there is good evidence that these substances can stimulate $\stackrel{\mathbb{D}}{-}$ proliferation of small cell lung cancer cells, thereby $\vec{\varphi}$ acting as autocrine growth factors. Further proof of ${ }^{\infty}$ this function came from a study where a monoclonal ${ }^{-}$ antibody to bombesin was used to block its binding to receptors on small cell lung cancer cells. ${ }^{17}$ Inhibition of clonal growth in vitro and regression of xenografts in vivo were seen. This novel approach to manipulating $\stackrel{\circ}{\mathbb{Q}}$ the growth of small cell lung cancer cells may offer $a$ more rational alternative to cytotoxic drugs in treating patients with small cell lung cancer. Clinical studies evaluating the use of bombesin antagonists or antireceptor antibodies in small cell lung cancer are eagerly awaited.

\section{Cytogenetic studies}

Continuous cell lines provide good specimens for $\delta$ conducting tumour cytogenetic analyses. Abnormalities in chromosome numbers and frequent structural 0 aberrations are seen in all small cell lung cancer cell lines. ${ }^{618-20}$ One study ${ }^{19}$ reported a consistent deletion of the whole or a portion of the short arm of chromosome 3. This abnormality appears to be an acquired somatic or cell defect specific to small cell lung cancer. The exact $\tilde{O}$ significance of its occurrence is unclear as little is known of the genes present in the $3 \mathrm{p}$ region and not all $\mathrm{O}$ studies of small cell lung cancer have confirmed the presence of this defect. ${ }^{18}$ Similar uncertainty regarding ${ }_{\bar{\Phi}}$ clinical relevance also exists over the reports of $\stackrel{\oplus}{?}$ amplification and expression of certain oncogenes by 0 lung cancer cell lines. ${ }^{21-23}$

Small cell lung cancer has many heterogeneous $\frac{\mathbb{\Phi}}{\odot}$ features with respect to morphology, functional $\mathbb{Q}$ ability, and DNA content. ${ }^{24}$ Although its cell lines $\sigma$ have been shown to have a DNA content similar to 
In vitro characteristics of small cell lung cancer and non-small cell lung cancer cell lines

\begin{tabular}{|c|c|c|c|}
\hline Property & $\begin{array}{l}\text { Small cell lung cancer } \\
\text { classic }\end{array}$ & $\begin{array}{l}\text { Small cell lung cancer } \\
\text { variant }\end{array}$ & Non-small cell lung cancer \\
\hline $\begin{array}{l}\text { Morphology } \\
\text { Culture appearance } \\
\text { Nucleoli } \\
\text { Nuclear : cytoplasmic ratio } \\
\text { Dense core granules } \\
\text { Growth properties } \\
\text { Doubling time (mean (SD)) } \\
\text { Cloning efficiency } \\
\text { Biochemical markers } \\
\text { L-dopa decarboxylase } \\
\text { Bombesin } \\
\text { Neurone specific enolase } \\
\text { Creatine kinase } \\
\text { Hormone production } \\
\text { Radiation sensitivity } \\
\text { C-myc oncogene }\end{array}$ & $\begin{array}{l}\text { Tight aggregates } \\
\text { Inconspicuous } \\
\text { High } \\
\text { Present } \\
72(12) \text { hours } \\
1-5 \% \\
\text { Increased } \\
\text { Increased } \\
\text { Increased } \\
\text { Increased } \\
\text { Frequent } \\
\text { Sensitive } \\
\text { Not amplified }\end{array}$ & $\begin{array}{l}\text { Loose aggregates } \\
\text { Prominent } \\
\text { Medium } \\
\text { Absent or rare } \\
33(2) \text { hours } \\
10-30 \% \\
\text { Absent } \\
\text { Absent } \\
\text { Increased } \\
\text { Increased } \\
\text { Seldom } \\
\text { Resistant } \\
\text { Often amplified }\end{array}$ & $\begin{array}{l}\text { Adherent growth } \\
\text { Prominent } \\
\text { Variable } \\
\text { Absent } \\
\text { About } 50 \text { hours } \\
0 \cdot 5-40 \% \\
\text { Absent } \\
\text { Absent } \\
\text { Absent or low } \\
\text { Absent or low } \\
\text { Seldom } \\
\text { Resistant } \\
\text { Occasionally amplified }\end{array}$ \\
\hline
\end{tabular}

that of their original tumour, ${ }^{25}$ there is now evidence that genetic instability may occur during prolonged growth and repeated passage in vitro. ${ }^{26}$ Does this property invalidate the use of continuous cell lines to study the biology of the disease?

Major alterations in tumour morphology, biochemistry, chemosensitivity, antigen expression, and DNA content have been observed in patients with small cell lung cancer. ${ }^{25}$ This suggests that tumour evolution in vivo is a dynamic process, perhaps caused by interactions between clonal subpopulations within any one lesion. Although the selection pressures that may cause these changes in patients (for example, host response, vascularity, treatment) may be different from those encountered by cells in vitro (for example, nutritional requirements, presence of growth and inhibitory factors), the fact that cell lines show genetic instability with time would not appear to invalidate them as experimental models.

The development of drug resistance in patients with small cell lung cancer, often after a dramatic initial response, is probably due in part to heterogeneity in the sensitivity of different subpopulations of cells within a small cell lung cancer tumour. Studying the genetic aspects of cell lines may provide important clues about the cause of this major clinical problem.

\section{Classic and variant cell lines}

After the comprehensive characterisation of small cell lung cancer cell lines by Minna and his colleagues, ${ }^{27}$ two distinct subgroups have emerged. Initially the classification of lines into "classic" and "variant" types was based on their expression of the key APUD enzyme L-dopa decarboxylase, which was absent in variants. Further studies showed important differences in morphology, growth properties, biochemistry, ${ }^{27}$ and radiosensitivity ${ }^{28}$ between the two groups (table). The classic group accounts for around $70 \%$ of small cell lung cancer cell lines, variant types comprising the remainder, though there is a certain degree of overlap between the groups. The variants have been further divided into two subclasses with altered biochemical and morphological characteristics. $^{29}$

The clinical importance of these two classes of cell lines remains uncertain. In general terms the variant group shows more "aggressive" in vitro behaviour than the classic group, with shorter doubling times, higher cloning efficiency, increased oncogene amplification, and decreased sensitivity to radiation. Morphologically, cells of the variant group often resemble large cell tumours and most variant lines have been established from patients with a mixed small cell and large cell morphology. Clinically these patients may have a poorer prognosis than those with the histological appearances of "pure" small cell lung cancer. ${ }^{30} 31$ Perhaps therefore the variants merely represent the in vitro model of this mixed cell subtype of small cell lung cancer.

The fact that the variant cell lines have been seen to evolve from classic cell lines over the passage of time, with loss of APUD properties and an increase in growth rate, ${ }^{27} 29$ adds weight to the idea that different histological subtypes of lung cancer may be seen within the same tumour. ${ }^{32}{ }^{33}$ It may also support the idea that all types of human lung cancer are derived from a common endodermal "stem cell" origin, ${ }^{34}$ although this evolution from classic to variant types would appear to represent a process of dedifferentiation.

\section{Conclusions}

Advances in tissue culture techniques have made it possible to establish and grow human lung cancer as 
continuous cell lines and as xenografts in rodents. Important characteristics of the original tumour such as morphology, chromosome number, and functional activity are retained by tumour cells in these models despite repeated passage over many years.

Over the past five years a wealth of information on the biology, biochemistry, and cytogenetics of human lung cancer has been generated by studies based on laboratory models. Much is now known about the specific growth requirements of lung cancer cells growing in vitro and the factors that regulate tumour cell proliferation. It is hoped that these advances in understanding can be translated into a form that would benefit patients with lung cancer. The development of newer, more effective treatment for patients with widespread disease is by far the most pressing need.

\section{RJ FERGUSSON JF SMYTH \\ Imperial Cancer Research Fund Medical Oncology Unit Department of Clinical Oncology Western General Hospital Edinburgh EH4 $2 \mathrm{XU}$}

\section{References}

1 Gropp C, Havemann K, Scheurer A. Ectopic hormones in lung cancer patients at diagnosis and during therapy. Cancer 1980;46:347-54.

2 Hansen $M$, Hammer M, Hummer L. Diagnostic and therapeutic implications of ectopic hormone production in small cell carcinoma of the lung. Thorax 1980;35:101-6.

3 Shimosato Y, Kameya T, Nagai K, et al. Transplantation of human tumors in nude mice. $J$ Natl Cancer Inst 1976;56:1251-60.

4 Shorthouse AJ, Carter SM, Ellison ML. Tumour marker production in human bronchial carcinoma xenografts. Oncodev Biol Med 1982;3:273-81.

5 Kondo Y, Mizumoto Y, Katayama S, et al. Inappropriate secretion of antidiuretic hormone in nude mice bearing a human bronchogenic oat cell carcinoma. Cancer Res 1981;41:1545-8.

6 Carney DN, Broder L, Edelstein M, et al. Experimental studies of the biology of human small cell lung cancer. Cancer Treat Reps 1983;67:27-35.

7 Sorenson GD, Pettengill OS, Brinck-Johnsen T, Cate CC, Maurer LH. Hormone production by cultures of smallcell carcinoma of the lung. Cancer 1981;47:1289-96.

8 Woo KB, Waalkes TP, Abeloff MD, Ettinger DS, McNitt L, Gehrke CW. Multiple biologic markers in the monitoring of treatment for patients with small cell carcinoma of the lung. Cancer 1981;48:1633-42.

9 Wallach S, Royston I, Taetle R, Wohl H, Deftos LJ. Plasma calcitonin as a marker of disease activity in patients with small cell carcinoma of the lung. $J$ Clin Endocrinol Metab 1981;53:602-6.

10 Tapia FJ, Barbosa AJA, Marangos PJ, et al. Neuron- specific enolase is produced by neuroendocrines tumours. Lancet 1981;i:808-11.

11 Carney DN, Marangos PJ, Ihde DC, et al. Serum neuron $\frac{\bar{y}}{\overline{\frac{1}{2}}}$ specific enolase: a marker for disease extent anc response to therapy of small-cell lung cancer. Lance $\mathcal{R}$ 1981;i:583-5.

12 Gazdar AF, Zweig MH, Carney DN, Van SteirteghenAC, Baylin SB, Minna JD. Levels of creatine kinase and its BB isoenzyme in lung cancer specimens and cultures. Cancer Res 1981;41:2773-7.

13 Kurtz KJ, Nielsen RD. Serum creatine kinase BB isoen $\overrightarrow{\vec{x}}$ zyme as a diagnostic aid in occult small cell lung cancer Cancer 1985;56:562-6.

14 Moody TW, Pert CB, Gazdar AF, Carney DN, Minnă JD. High levels of intracellular bombesin characterizeo human small-cell lung carcinoma. Scienc£ 1981;214:1246-8.

15 Erisman MD, Lonnoila RI, Hernandez O, Di Augustine RP, Lazarus LH. Human lung small-cell carcinoma contains bombesin. Proc Natl Acad Sci 1982;79: 2379-83.

16 Moody TW, Bertness V, Carney DN. Bombesin-lik peptides and receptors in human tumors. Peptide 1983;4:683-6.

17 Cuttitta F, Carney DN, Mulshine J, et al. Bombesin-like0 peptides can function as autocrine growth factors in human small-cell lung cancer. Nature 1985;316:823-6응

18 Wurster-Hill DH, Cannizzaro LA, Pettengill OS, Soren son GD, Cate CC, Maurer LH. Cytogenetics of smalf cell carcinoma of the lung. Cancer Genet Cytogened 1984;13:303-30.

19 Whang-Peng J, Kao-Shun CS, Lee EC, et al. Specific chromosome defect associated with human small-cel lung cancer: deletion 3p (14-23). Science 1982;215 181-2.

20 Wurster-Hill DH, Maurer LH. Cytogenetic diagnosis of. cancer: abnormalities of chromosomes and polypoidf levels in the bone marrow of patients with small cet $\mathbb{Q}$ anaplastic carcinoma of the lung. $J$ Natl Cancer Ins 1978;61:1065-75.

21 Griffin CA, Baylin SB. Expression of the c-myb oncogene. in human small cell lung carcinoma. Cancer Reig 1985;45:272-5.

22 Saksela K, Bergh J, Lehto V-P, Nilsson K, Alitalo $\mathrm{K}_{0}$ Amplification of the c-myc oncogene in a subpopulation of human small cell lung cancer. Cancer Re? 1985; 45:1823-7.

23 Little CD, Nau MM, Carney DN, Gazdar AF, Minna JD. Amplification and expression of the c-myc oncogene in human lung cancer cell lines. NaturE 1983;306:194-6.

24 Matthews MJ, Gazdar AF. Changing histology in malig nant tumors: diagnostic and therapeutic significance Eur J Cancer Clin Oncol 1985;21:549-52.

25 Gazdar AF, Minna JD. Cell lines as an investigation tool for the study of biology of small cell lung cancer. Eur J Cancer Clin Oncol 1986;22:909-11.

26 Engelholm SA, Vindelov LL, Spang-Thomsen M, et a? Genetic instability of cell lines derived from a single human small cell carcinoma of the lung. Eur $J$ Canceg Clin Oncol 1985;21:815-24.

27 Carney DN, Gazdar AF, Bepler G, et al. Establishment 
and identification of small cell lung cancer lines having classic and variant feature. Cancer Res 1985;45: 2913-23.

28 Carney DN, Mitchell JB, Kinsella TJ. In-vitro radiation and chemotherapy sensitivity of established cell lines of human cell lung cancer and its large cell variants. Cancer Res 1983;43:2806-11.

29 Gazdar AF, Carney DN, Nau MM, Minna JD. Characterization of variant subclasses of cell lines derived from small cell lung cancer having distinctive biochemical, morphological and growth properties. Cancer Res 1985;45:2924-30.

30 Hirsch FR, Osterlind K, Hansen HH. The prognostic significance of histopathologic subtyping of small cell carcinoma of the lung according to the World Health Organization. Cancer 1983;52:2144-58.
31 Radice PA, Matthews MJ, Ihde DC, et al. The clinical behaviour of "mixed" small cell/large cell bronchogenic carcinoma compared to "pure" small cell subtypes. Cancer 1982:50:2894-902.

32 Brereton HD, Mathews MM, Costa J, Kent CH, Johnson RE. Mixed anaplastic small-cell and squamous-cell carcinoma of the lung. Ann Intern Med 1978;88:805-6.

33 Abeloff MD, Eggleston JC, Mendelsohn G, Ettinger DS, Baylin SB. Changes in morphologic and biochemical characteristics of small cell carcinoma of the lung. Am J Med 1979;66:757-62.

34 Banks-Schlegel SP, Gazdar AF, Harris CC. Intermediate filament and cross-linked envelope expression in human lung tumor cell lines. Cancer Res 1985;45: 1187-97. 